\title{
Evolution of indigenous tourism among the Lacandon of Chiapas: an application of Weaver's model
}

\author{
Pilar Espeso-Molinero
}

Social Anthropology Department, University of Alicante, Alicante, Spain

http://orcid.org/0000-0001-5876-3906

\section{p.espeso@ua.es}

Carretera San Vicente del Raspeig s/n

03690 San Vicente del Raspeig - Alicante

Tel. 965903432 - Fax 965903464

\section{María José Pastor-Alfonso}

Social Anthropology Department, University of Alicante, Alicante, Spain

http://orcid.org/0000-0001-8820-8073

\section{Josefa.pastor@ua.es}

Carretera San Vicente del Raspeig s/n

03690 San Vicente del Raspeig - Alicante

Tel. 965903430 - Fax 965903464

Corresponding author: p.espeso@ua.es

Dr. Pilar Espeso-Molinero is a researcher at the University Institute of Tourism Research and lecturer at the University of Alicante, Spain. Her research concerns the potential of Indigenous tourism operators to design and implement tourism products, capitalizing on their own culture and local resources. From a decolonizing and critical perspective, she employs action research methods and creativity tools to explore the integration of traditional and scientific knowledge in the tourism arena.

Dr. María José Pastor-Alfonso is a researcher at the University Institute of Tourism Research, University of Alicante, Spain. She has conducted extensive field work in Venezuela and Mexico. Her research focuses on the relationship between tourism, culture, heritage, identity and the environment. Her most recent work has focused on the sociocultural impacts of tourism in Indigenous communities from a decolonizing perspective. 


\section{Evolution of indigenous tourism among the Lacandon of Chiapas: an application of Weaver's model}

In this paper, Weaver's six-stage indigenous tourism model is applied to the Lacandon Maya (Hach Winik) of Chiapas, Mexico. Based on a comprehensive review of the anthropological and historical literature on this indigenous group, combined with longitudinal ethnographic and collaborative research performed with tourism entrepreneurs, the Lacandon tourism experience is assessed from the pre-European period until present. By analysing a case study of indigenous tourism in Mexico, a developing country in another geographical region and with a different colonial past, this work supplements Weavers' perspective. The results show that the fourth and fifth stages of Weaver's model coincide in this case study, while the sixth stage is still incomplete. Although the Lacandon case has its peculiarities and bearing in mind that several different factors should be considered in the Latin American context, the model proves to be an interesting tool for indigenous tourism analysis in developing countries.

Key words: Indigenous tourism; empowerment; sustainability; Weaver's Model; Mexico.

\section{Introduction}

Since 1974, when Valene Smith organised the first symposium on tourism and anthropology, the indigenous tourism concept has received greater attention from academics and practitioners (Butler \& Hinch, 1996; Buultjens \& Fuller, 2007; Carr, Ruhanen, \& Whitford, 2016; Lemelin \& Blangy, 2009; Ryan \& Aicken, 2005; Smith, 1977). The growing body of literature studies the phenomenon from the perspectives of hosts (McIntosh, Zygadlo, \& Matunga, 2004) and visitors (McIntosh \& Ryan, 2007) alike. And although very few works have attempted to conceptualise the evolution of the relationship between tourism and indigenous peoples, a notable exception is 
Weaver's paper on indigenous tourism stages and their implications for sustainability (2010).

After studying more than 200 academic and professional documents on indigenous tourism, Weaver developed a six-stage evolution model of the relationship between tourism and indigenous peoples: (1) pre-European in situ control; (2) in situ exposure; (3) ex situ exhibitionism and exploitation; (4) in situ exhibitionism and exploitation; (5) in situ quasi-empowerment; and (6) ex situ quasi-empowerment. In his analysis of the dynamics of empowerment and its implications for sustainability, he acknowledges two main limitations: the absence of indigenous 'voices' among his sources and a corpus containing only English-language documents, thus restricting the focus of his research to cases in Australia, Canada, New Zealand and the United States. He also considers that it 'is unlikely that case studies from less economically developed regions in Latin America, Africa, Asia and the South Pacific in particular will reveal the full six-stage progression' (Weaver, 2010, p.56).

Therefore, an attempt is made here to overcome those limitations by applying Weaver's model to a case study of the evolution of tourism among the Lacandon Maya Indians (also known as the Hach Winik, i.e. 'true men') living in the jungles of Chiapas, near the southern border with Guatemala.

Following Weaver's example, this paper examines both written ethnographies the Lacandon Maya have received considerable scholarly attention and consequently there is an extensive body of anthropological and historical literature that facilitates the understanding of the evolution of tourism in their communities - and government documents. On the other hand, thanks to the long-term collaboration between the Intercultural University of Chiapas (UNICH) in Mexico, the University of Alicante (UA) in Spain and the tourism entrepreneurs of the Lacandon Jungle, a collaborative 
team of researchers have produced accounts of different aspects of the relationship between the Lacandon communities and the tourism industry, thus providing primary data for this analysis.

The economy of the Lacandon Maya was based on subsistence farming, hunting and fishing until tourism took centre stage. As will be seen, its evolution in the area has much in common with Weaver's stages. However, the political and social idiosyncrasies of this small but powerful group have created different resistance dynamics that deserve further discussion in order to add a new perspective to Weaver's model.

\section{The Lacandon People}

Despite being one of the least numerous indigenous groups in Mesoamerica, the Lacandon Maya have constantly fascinated visitors and scholars alike. They live in one of the planet's most biodiverse areas and, over time, have acquired a fund of knowledge in agriculture, botany, natural medicine, etc. Their customs and ancestral beliefs continue to arose the interest of academics, the attention of the media and, lately, also the curiosity of tourists, eager to discover a reality very different from their own.

Enhancing the destination's appeal, the Lacandon Jungle encompasses the legacy of the Classic Maya, who left behind remains of important cities such as Palenque, Bonampak and Yaxchilán. Since the first expeditions reached the area at the end of the nineteenth century, the Lacandon Maya have offered their hospitality to both friends and strangers. More recently, with the active support of the state and national governments, they have begun to convert their traditional hospitality into a tourist business.

\section{Habitat and history}


According to the French ethnologist Soustelle's description in 1935 (1935/2008), 'the entire Lacandon territory is muddy, swampy, extremely humid' (p. 15) and is bordered by a mighty river containing the waters of numerous tributaries that run through the jungle. Multiple lakes and lagoons also dot the territory, 'like mirrors of jade in the middle of the forests' (Soustelle, 1935/2008, p.15), making it one of the areas with the highest concentration of surface water in Mexico (Pastor-Alfonso, 2012).

The Hach Winik have been living in the jungles of Chiapas for the past three centuries. Their dominions, language and traditions, with obvious Mayan connections, led the first explores and scholars to assume that they were the Lacam-tun people, to wit, direct descendants of the Maya. However, historical (de Vos, 1980; Palka, 2005) and linguistic research (Bruce, 1968) has finally dispelled the myth of historical continuity with the pre-Columbian past in Mexico, demonstrating that they are two different groups. The Lacam-tun people, called the 'Lacandon' by the Spanish colonisers, were a bellicose pre-Hispanic indigenous group that fought relentlessly for their freedom against the 'usurpers ${ }^{1}$ until the point of total extinction (de Vos, 1980). After subduing the natives, the Spaniards encountered difficulties in colonising the area and soon left. The abandoned settlements were then occupied by other Mayan groups that had been pushed out of other areas of the ancient Mayan empire by colonisation (Palka, 2005). Little else is known about their origins.

The following centuries passed in a very similar manner for the Lacandon. Their traditional settlements were scattered throughout the rainforest in two distinctive groups, north and south, with some linguistic and cultural differences, until the Mexican land reforms in the 1950s opened up the jungle to colonisation and industrial exploitation. Encouraged by agrarian reforms, Tzeltal, Tzotzil and Chol immigrants

\footnotetext{
${ }^{1}$ Marie-Odile Marion (1999, p.10) recovers the term 'usurpers', used by the Maya in the Chilam Balam books, to designate the Spanish conquerors.
} 
from the highlands and the northern reaches of Chiapas begin to settle in the lowlands, bringing with them their own traditional ways of subsistence unrelated to the jungle economy.

Migratory pressure combined with political incentives forced the Lacandon to unify their settlements. Consequently, the dispersed pattern of family clusters disappeared to be replaced by the modern-day communities of Nahá, Metzabok (north) and Lacanjá Chansayab (south).

\section{Development and tourism among the Lacandon people}

Although logging and cattle ranching have transformed the traditional way of life of the Lacandon, the most obvious changes have been brought about by the development of tourism in the area. Government support for tourism as a socio-economic alternative and a way of protecting the environment began at the end of the twentieth century. The close collaboration that the Lacandon have maintained with the state and national authorities since the 1970s has placed this small group in a privileged and unprecedented position as regards other indigenous groups. Despite their small population, they have received generous funding from the different administrations (Pastor-Alfonso, Gómez López, \& Espeso-Molinero, 2012). Furthermore, they have been granted privileges, such as archaeological returns (access to the Bonampak Natural Monument), control over three protected areas (Metzabok, Nahá and Montes Azules), and extensive lands with diverse natural and ecotourism attractions (waterfalls, lagoons, etc.). Through different public programmes, in conjunction with local initiatives and with the support of NGOs and universities, they have consolidated a wide range of nature tourism facilities and services, which for many families have replaced traditional economic activities (Pastor-Alfonso, 2012). 


\section{The Lacandon in the academic literature}

Following the arrival of the ethnologist Alfred M. Tozzer (1907) at the beginning of the twentieth century, there have been expeditions to the Lacandon Jungle without pause. In addition to numerous general monographs on the Hach Winik (Boremanse, 1998; Eroza Solana, 2006; Marion Singer, 1999; McGee, 2002; Perera \& Bruce, 1985), anthropologists, linguists, ethnologists and historians have focused their attention on specific topics, such as the Mayan language of the Lacandon (Bruce, 1968), their cosmology (Marion Singer, 2000), religious rituals (Boremanse, 2007; McGee, 1990; Tozzer, 1907) and funerals rites (Blom, 1954). Researchers have also concentrated on their impressive oral tradition (Bruce, 1976), with its rich mythology (Boremanse, 1989; Bruce, 1979), their social, family and gender organisation (Marion Singer, 1999; McGee \& González, 1999), their ethnobotanical knowledge and use of medicinal plants (Kashanipour \& McGee, 2004), their subsistence economy based on agriculture and hunting (Baer \& Merrifield, 1972; Diemont \& Martin, 2009) and the technologies that they have developed in this respect (Marion Singer, 1991; Nations \& Clark, 1983).

Similarly, many works address the controversy surrounding the historical evolution of the Lacandon Maya (Baer \& Merrifield, 1972; de Vos, 1980; 2002; Palka, 2005). And in recent years there has been a clear trend towards studies focusing on traditional ecological knowledge (Diemont \& Martin, 2009), the political controversy over land rights (Calleros-Rodríguez, 2014; Trench, 2008), environmental management (Durand, Figueroa, \& Trench, 2012; Reygadas, Ramos, Montoya Gómez, Hernández, \& Velasco, 2006) and the arrival of tourism in the Lacandon communities (EspesoMolinero, Carlisle, \& Pastor-Alfonso, 2016; Espeso-Molinero, 2018; Hernandez Cruz, 
Bello-Baltazar, Montoya Gómez, \& Estrada Lugo, 2005; López \& Palomino, 2008; Pastor-Alfonso \& Gómez López, 2010; Pastor-Alfonso, 2012; Valle-García, 2014).

In this extensive and varied production, there is only one issue that crops up time and again: the advance of global acculturation and the inexorable loss of Lacandon mores. Evangelicalism and formal education, with its nationalist symbols and biased views on the historical past, have gradually encroached on the mythical Lacandon cosmology. As many authors (Boremanse, 2006; McGee, 2002; Valle-García, 2014) have already indicated, agricultural transformation as regards techniques and crops and diet changes are gradually eroding the indigenous people's gastronomic, botanical and ethnomedicinal knowledge base, leading to irreversible cultural changes. In contrast, only a few studies have underscored the opportunities afforded by tourism-related activities for cultural revival (Espeso-Molinero et al., 2016; Espeso-Molinero, 2018).

\section{Lacandon tourism according to Weaver's model}

In 2010, Weaver proposed a model to 'assess the evolution of the relationship between tourism and indigenous peoples' (p. 43). Employing the control/theme matrix developed by Hinch and Butler in 1996 as a 'framework for contextualizing and visualizing' (p. 46) the basic variables, his model represents an ideal six-stage evolution.

\section{Stage one: in situ control}

The first stage of Weaver's model considers the phase prior to European colonisation and would refer to activities carried out by indigenous peoples as part of their ancestral customs. Ceremonial reunions and gift exchanges between neighbouring groups or corroborees, celebrated as much between the North American Indians (potlatch) as between the Maori (koha), involved displacements and situations that today would be 
recognised as tourism activities. This 'pre-European' stage was controlled in situ by indigenous groups.

In the Lacandon context, the ethnocide of the Lacam-tun group prevents us from understanding indigenous meeting, ceremonial reunion or gift exchange practices prior to the Spanish colonisation. Among the Hach Winik, there are no ceremonial meetings among neighbours. For many years, this indigenous group was accustomed to war and perhaps because of this, not especially inclined to interact with other groups (Boremanse, 1998). Their constant need to defend themselves against the Spanish military, the Catholic missionaries, other indigenous groups and even other Lacandon communities (the Lacandon of the south were renowned for both their violent nature and habitual practice of abducting women for marital purposes) prompted especially those from the north to disperse and seek isolation. So, in principle, it seems that those from the north preferred to avoid contact with the inhabitants of other settlements and visits were only paid for specific reasons (e.g. newlyweds used to regularly visit the parents of the bride or groom during their first year of marriage).

However, 'the Lacandones often make long journeys on foot to the shrines of their various gods. The women accompany the men on these trips, often carrying a child astride the hips, together with another swung on a net on the back' (Tozzer, 1907, p.24). In the past, they used to change settlements to avoid epidemics or in search of better lands for agriculture or hunting. Following the nomadic cycle of their crops, every four or five years they moved on to a different place, but always in the same environment, thus enabling an optimal understanding of the rainforest and its resources. They also went on expeditions to other parts of the forest to hunt, fish or visit family and friends.

As regards other ancestral costumes, cords made of $k^{\prime} u c h$ cotton thread for the sick or parturient were a fundamental aspect of life. Married women prepared healing 
cords for family, friends and even a favourite dog by rolling the thread with their hands to create a cord that was then placed around the neck of the sick person or on an injured limb and left there until it fell off on its own accord. Only married women could do this because the rite was related to the power of the umbilical cord. The cords were not really for healing, but a symbol of solidarity (Boremanse, 1998). They involved a kind of spell that women cast to prevent evil from returning to them. If a woman knew that someone was sick and did not give him or her a cord, and her negligence contributed to the death of the patient, the soul of the deceased could return to seek revenge on her (McGee, 2002). Since women did not place these cords on members of their own household, if a Lacandon woman knew of another person's illness or pregnancy, she or her husband had to visit the patient or pregnant women to offer them a cord. Paying visits formed part of a more complete trip for hunting, searching for materials or other purposes.

Until the 1970s, a very strict ritual was followed during Lacandon visits, above all in the north. Boremanse (1998) offers us the following description:

The visitors who have come from a different settlement stop about forty meters from the first household of the group they intend to visit. They hide their rifles (in the past their bows and arrows) and net bags in the bushes by the trail. (...) One of the travelers then hits a tree trunk with his machete (...) to call the attention of the people who are going to be visited. (...) A little while after hearing the signal, the eldest man of the cluster, or the head of the household that is situated nearest the trail (...) goes to see who has come, but without any hurry. (...) After they have announced themselves, (...) all the members of the party hide in the bushes (p.18-19). 
The head of the household then sat by the trail and struck up a conversation with the visitors' spokesperson, while the rest of the group remained hidden in the undergrowth. Finally, after a brief chat, the host formally invited the travellers to enter his house, taking his leave to warn the womenfolk of the visit and to make the necessary arrangements. Five minutes later, the guests followed him, leaving behind their belongings, especially their rifles or bows and arrows, hidden in the bushes on the roadside, and carrying only their leather bags with personal items. Once inside the house, the visitors settled near the door or in a separate cabin, from where they rarely moved (Boremanse, 1998, p.21). They only spoke with the host and his wife, while always avoiding eye contact. At a certain moment, visiting women got up to tie a $k^{\prime} u c h$ on the right wrist of a new-born baby or someone sick. Other members of the household or other households in the family cluster did not participate in the visit, even if they were close relatives or friends. And if the visitors were still there at nightfall, they went to fetch their belongings and upon returning handed their weapons over to their host.

As to sleeping arrangements, visitors remained in the same area, near the house's threshold. The men continued chatting for quite a time, while the women and children rested. The conversation continued to be very formal, until late into the night when it became more relaxed. During the visit, the host offered his visitors tobacco and tortillas for dinner. If they wanted to purchase products not grown in their own fields, the host refused payment or offered, in exchange for money, a larger amount of the product. 'This typical behavior denotes a practice of gifts and counter-gifts that does not occur outside the context of hospitality' (Boremanse, 1998, p.21). 
In contrast, the Southern Lacandon Indians did not need any pretext to visit neighbours or friends. Upon arrival, they whistled and their hosts received them without further ado, offering them something to drink and often a full dinner. These practices were reciprocal, guests inviting their hosts to return the visit as soon as it was a good time to hunt.

\section{Stage two: in situ exposure}

This stage would be represented by the first expeditions of explorers, anthropologists and scientists into unknown lands, motivated by curiosity or economic and military interests. They left long accounts of the culture of these groups for fear that they would disappear in the name of 'progress' (Weaver, 2010).

Until the mid-twentieth century, the Lacandon Jungle was a practically uninhabited and very isolated place, without paved roads or electricity. To reach the Lacandon communities it was necessary to cover long distances on horseback, by boat along the Usumacinta River or by plane followed by hard trekking through the jungle. Even so, loggers, rubber tappers and numerous researchers and adventurers journeyed into the rainforest in search of riches or knowledge.

Through these contacts, the Hach Winik soon begin to understand the rules of hospitality and exchange with strangers. Since the first academic expeditions of Tozzer, Soustelle and Blom, the discovery of the Bonampak remains and the arrival of the first allocentric tourists, many indigenous families in all communities began to provide researchers and travellers with food and shelter. But these first initiatives, although confirming the 'warm and generous' nature of Lacandon hospitality (Boremanse, 1998, p.24), cannot yet be considered tourist activities. Weaver (2010, p.47) calls this stage 'in situ exposure' because in these first encounters indigenous 
people were the object of curious observation by Westerners. According to Hinch and Butler's matrix (2007), the theme is still clearly indigenous but control begins to be more transitional, inadvertently passing into non-indigenous hands.

\section{Stage three: ex situ exhibitionism and exploitation}

According to Weaver (2010), this stage is characterised by the exhibitionism and exploitation of the natives outside their territory, with a clear interest in highlighting their savage character in opposition to Western civilisation. The early accounts of researchers and explorers aroused the curiosity of their compatriots, thus fostering the development of indigenous exhibitions and museums displaying native artefacts and handicrafts in North America and Europe. Their interpretation reinforced the 'moral superiority' of Eurocentric views, portraying indigenous cultures as backward. The dehumanisation of indigenous peoples was even taken a step further with the exhibition of individuals at fairs all over the world.

For the Lacandon people, this is the stage when legend was forged. The stories of the first explorers, together with the ethnographic works of the first half of the twentieth century, breathed life into the myth of continuity between the ancient Mayan civilisations and the recently rediscovered Lacandon, turning them into 'the last lords of Palenque'. According to these early accounts, the Lacandon had managed to eschew the Spanish conquest thanks to the isolation provided by the rainforest. The essence of the noble savage myth and Eurocentric exoticism found an ideal breeding ground in this group. However, Trench (2005, p.49) emphasises the contradictions of this period in which, for example, Franz and Trudy Blom described the Lacandon as 'lords of an immense kingdom', while treating them like 'savages'. 
For his part, Perera recalls his first contact with the Lacandon in 1938 (Perera \& Bruce, 1985), when his father took him to a fair organised by the President of Guatemala, General Jorge Ubico, who wanted representatives of all the Mayan tribes exhibited at it.

In the middle of this enclosure, behind a barbed-wire fence guarded by soldiers, a group of five Lacandon Indians was housed in a small hut of bamboo and palm thatch intended to duplicate their jungle home. They wore long white tunics and had shoulder-length matted hair, so it was difficult to tell if they were men or women. (...) One of the men came out of the hut and walked right to the fence where we stood. He made a noise in his throat and stuck his hand through the fence. Before I could overcome my bewilderment and decided whether to offer him a coin or the piece of chocolate I had in my pocket, a soldier pulled him away. The look of sadness and confusion in his eyes will stay with me forever (Perera \& Bruce, 1985, p.36).

These Lacandon Indians had been deceived and illegally abducted to satisfy the curiosity of the Guatemalan elites. $^{2}$

The representations of the Lacandon as 'savages' are as plentiful as the descriptions of these people as the principle heirs to the Mayan culture. Pereira remembers his upbringing in Guatemala, where the 'savagery' of the Lacandon was

\footnotetext{
${ }^{2}$ Against the wishes of Major Bickford, who intended to establish a permanent exhibition featuring the Lacandon, Mario Monteforte Toledo, leader of the adventurers who had taken them to Guatemala, kept his promise to return them to the jungle after the fair. During their stay in Guatemala, they all suffered from lung problems and gastroenteritis. One of the five never returned.
} 
used to scare children: 'Eat all your beans or the Lacandon will get you.' Others mocked their primitive way of life by referring to them as 'one of those who live like a monkey, in the jungles of El Petén' (Perera \& Bruce, 1985, p.37).

Like elsewhere, the first images of the Lacandon served for the 'appropriation and exploitation of indigenous culture to market the broader tourism industry, as seen in the prominence of stereotyped postcard images' (Weaver, 2010, p.49), thus contributing to turn the Lacandon into the iconic symbol of Chiapas indigenousness.

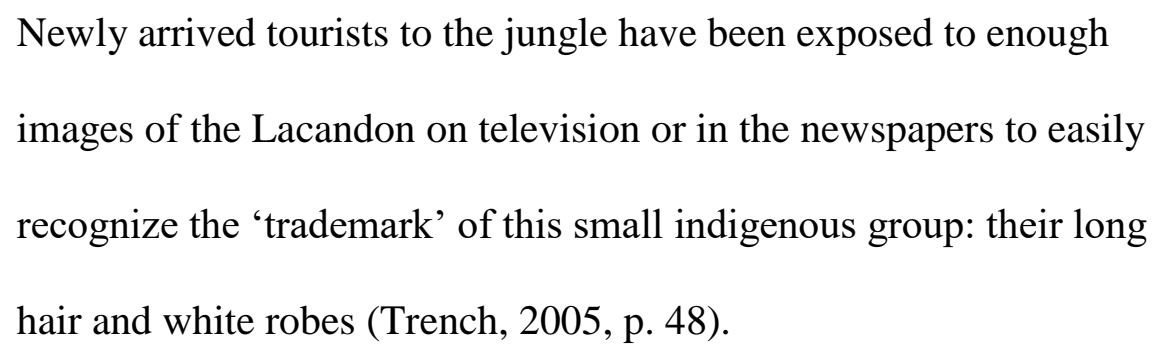

Therefore this stage implies a clear loss of control, where the indigenous theme is still present but clearly manipulated in the interests of the colonising group (Weaver, 2010).

\section{Stage four: in situ exhibitionism and exploitation}

With the arrival of mass transportation, peripheral areas are no longer isolated and a more articulated system of tourism can be introduced into indigenous territories. The first organised visits consist of staged representations of the native culture, where the interaction between tourists and locals is generally limited to buying cheap handicrafts and taking photographs. These activities are always organised by intermediaries outside the community who establish the rules and reap the benefits. The loss of control is absolute in this stage and the exhibitionism and exploitation of indigenous peoples happens in situ. However, it is also in this context that the first actions of resistance 
begin to take shape. In situ contact allows indigenous people to get to know and understand tourists, while these are still ignorant of the local culture, thus giving them power over the relationship and generating opportunities for control and resistance (Weaver, 2010).

The evolution of Lacandon tourism differs slightly from that presented by Weaver insofar as outside interest in 'ethnic art' and 'pan-Indian art' had an impact on Lacandon lives before the tourists themselves. In the Lacandon rainforest, the economic relationship between the natives and mass tourism began while jungle trails were still impassable for mass transportation. The daily arrival of small planes at Bonampak in the 1970s (Boremanse, 1998), as well as an increase in cultural tourism in Palenque in the following decade (McGee, 2002), opened up a market for Lacandon handicrafts. Men began to make bows and arrows expressly for the tourist market, while women saw in the traditional manufacture of necklaces and seed bracelets a source of monetary income. For the Lacandon, this development coincided with a wave of immigration and greater contact with the outside world. Their subsistence and exchange economy became insufficient and the need for hard cash pressing. In 1991, Marion Singer wrote that 'the Lacandon of Nahá and Metzabok could hardly meet all their new needs without the help of tourism' (p.232). In Lacanjá Chansayab, despite the diversification measures implemented by the Government, Boremanse (1998, p.9) states that 'in 1990, many of them [Lacandon] still relied on the sale of bows and arrows to tourists as a source of cash.'

In the early 1990s, notwithstanding the growing dependence on the tourist industry, the limited road infrastructure continued to prevent tourists from reaching the heart of the jungle and, therefore, the relationship of the Lacandon with tourism remained fundamentally ex situ. During this period, Nahá and Metzabok still received 
the same type of visitors as in the previous stage, i.e. adventurers and academics. In Lacanjá Chansayab, the tourists arriving by plane to visit the Bonampak archaeological site only stayed a few hours, their contact with the natives being restricted to the transport service from the airstrip to the site and to some hastily taken snapshots.

Despite the daytrip character of these visitors, the contacts developed in Bonampak match the framework proposed by Weaver. Even though the commercial exchange was dominated by intermediaries, it led to the first attempts at control among the indigenous people.

In the 1970s small planes transporting German, American, French, and Mexican tourist, returning from the Maya ruins of Bonampak or Yaxchilán, landed almost daily at Lacanha' Chan Sayab. On the airstrip they took pictures of Southern Lacandon men and women, who asked them for money for cigarettes and tried to sell them sets of bows and arrows as well as homemade necklaces. The Lacandon also poked fun at the tourists who were usually disappointed (Boremanse, 1998, p.10).

The Lacandon mockery of tourists recalls the examples studied by EvansPritchard (1989) among the Pueblo and Navajo Indians of New Mexico, where 'indigenous people maintained their dignity by caricaturing visiting tourists, often with the latter being unaware of the parody' (Weaver, 2010, p.54). The contacts in the jungle gave the Lacandon an opportunity to learn about international travellers, thus opening up opportunities for control and resistance. 


\section{Stage five: in situ quasi-empowerment}

For Weaver, the beginning of the fifth stage is marked by the emergence of communitybased tourism and ecotourism models, through which native groups begin to exercise 'formal control over tourism within indigenous areas' (2010, p.49) by determining sacred spaces, restricting access to their lands and participating actively in the design of tourism development programmes and cultural products. These dynamics are supported by new policies and funding at a national/regional and international level, as well as the advent of indigenous tourism associations.

This is the case with the Lacandon people. Funded by different institutions at all government levels, community-based tourism and ecotourism have been steadily promoted in the area over the past 20 years (López \& Palomino, 2012; Palomino \& López, 2007; Pastor-Alfonso et al., 2012). Through these public programmes run in conjunction with local initiatives and supported by NGOs and universities, the Lacandon have managed to consolidate solid tourism offerings that have replaced traditional economic activities for many families (Pastor-Alfonso, 2012).

As mentioned previously, the fourth stage of Weaver's model is characterised by the 'diffusion of mass transportation networks into peripheral areas' (Weaver, 2010, p.49) and the consequent arrival of mass tourism to indigenous lands, while the fifth is identified by a greater degree of empowerment, the recovery of indigenous rights and the subsequent control of tourism activities.

In the Lacandon Jungle, both phenomena occurred simultaneously, uniting the fourth and fifth stages of Weaver's model in one. Mass transportation and, therefore, the Lacandon's real participation in the tourism industry started in 1997 when President Ernesto Zedillo Ponce de León officially opened the southern border highway, between Palenque and Montebello Lakes National Park, connecting Lacanjá Chansayab with 
the main tourist hubs. By facilitating access to the rainforest, the destination was suddenly opened up to the national and international tourism markets. However, the decision to open the highway was really a counter-insurgency measure to control the Zapatista indigenous uprising. Therefore, the real development of tourism in Lacandon territory took place against a backdrop of struggle for indigenous peoples' human rights. Moreover, the indirect publicity generated by the Zapatista movement, especially among Europeans, became a driving force behind tourism development in the area (Reygadas et al., 2006, p.83).

Between 1994 and 2003, new roads between different jungle communities were built; however, Nahá and Metzabok continued to be connected by dirt roads, particularly unpredictable in the rainy season, ${ }^{3}$ thus safeguarding the Northern Lacandon destinations from a tourist invasion.

Despite the control over tourism exercised by local groups, together with the land rights granted to the Lacandon in 1972, we cannot yet speak of real empowerment. Weaver calls it 'quasi-empowerment' to reflect the existence of other problems that, as Johnston (2006) rightly points out, still exist: corruption, paternalism, dependency, mismanagement, exploitation, etc. 'A long history of alliances with and subordination to state agencies has made the Lacandon a very dependent group habituated to a patronage relationship with external institutions' (Reygadas et al., 2006, p.84).

\section{Stage six: ex situ quasi-empowerment}

According to Weaver's model, the sixth and current evolutionary stage would be characterised by the expansion of the geopolitical, economic and cultural influence of

\footnotetext{
${ }^{3}$ The soil of the Lacandon rainforest is composed of sedimentary rocks from the Cretaceous period, giving rise to relatively impermeable subsoil which favours runoff and soil erosion (Eroza Solana, 2006). In the rainy season, the rainforest's dirt roads are often blocked by landslides.
} 
indigenous people outside their own sphere, i.e. ex-situ control. This stage involves the restitution of land rights, the legal and academic recognition of traditional knowledge, a growing respect for indigenous culture and values, equitable benefit sharing, civil rights and a political voice at local and national levels.

These rights, although ratified by the United Nations, are constantly in conflict with the interests of the dominant culture, above all as regards natural parks and other protected areas in which it has a limited stake and the presence of indigenous groups is high. Solutions to conflicting values and objectives usually take the shape of 'joint management' and 'co-management' schemes.

The political situation of the Lacandon is exceptional when compared to other indigenous groups. The restitution of communal lands, among other privileges, was granted to them in 1971 (de Vos, 2002). This political move was premeditated and the underlying interests had very little to do with indigenous well-being (Nations, 1979; Trench, 2008). However, it coincided with was a growing international awareness of the marginalised situation of indigenous peoples around the globe (Martínez Cobo, 1986), 36 years before the UN Declaration on the Rights of Indigenous Peoples.

In light of such an exceptional situation, some of the characteristics of the sixth stage are far from being applicable to the Lacandon, accustomed to exercising their rights (and even their privileges) for more than 40 years. Nevertheless, as already noted, this close relationship with the Government has led to a serious patronage problem.

In addition, 'advances in terms of environmental governance have also been contradictory' (Reygadas et al., 2006, p.83). Despite the use of participatory methods in the design of the Montes Azules Biosphere Reserve (REBIMA) management plan, Reyagadas et al. (2006, p. 83) note that, in practice, local participation is merely formal. In fact, the reserve has a highly bureaucratic vertical management structure. In recent 
years, significant improvements have been observed, 'participation in REBIMA has been strengthened and there is undoubtedly a genuine interest of CONANP [national parks authority] and its staff to integrate and consider the views of communities in the management of the reserve' (Durand et al., 2012, p.264). However, the endless red tape, the inequalities in each indigenous group and between groups, and the lack of political voice all mean that 'participation in REBIMA and other nearby protected areas such as MN Bonampak and Yaxchilán (...) has not yet managed to ensure the inclusion of all the affected or interested parties' (p.265).

On the other hand, Weaver observes that in this sixth stage there is a greater indigenous presence in typical Western market economy activities, what Hinch and Butler (2007) call 'diversified indigenous' activities where there is control, but the indigenous theme disappears. Although it is possible to observe a certain disconnection between indigenous cultural themes and the tourism offering in the Lacandon Jungle, from the authors' point of view, this is not an empowerment outcome, but rather the effect of outside interests.

Product 'diversification' is mainly a result of joint-ventures with non-indigenous capital and entrepreneurship, in step with national tourism strategies that are encouraging adventure tourism over the cultural or 'dual track' kind. Some examples are the kayak activities offered by the Rio Lacanjá Camp in association with the company Explora, ecotourism and adventure in San Cristóbal de las Casas, and the buggies, kayaks and rafting activities recently promoted by Indigenous Treasures and managed by the company VDP Consultores, both non-indigenous organisations based in Mexico City.

So, instead of cases of 'shadow indigenous tourism', there are situations of 'quasiempowerment' more characteristic of the previous stage. However, through 
collaborative research strategies with local entrepreneurs, a strong interest in cultural revival has been identified (Espeso-Molinero et al., 2016). As has happened elsewhere (Esman, 1984; Henderson, 2003; Smith, 1989), tourism has increased the self-esteem of the Lacandon and their appreciation of the traditional values that make them unique (Pastor-Alfonso \& Gómez López, 2010; Pastor-Alfonso, 2012), as well as leading to a revival of local crafts (McGee, 2002). Nonetheless, contrary to the examples presented by McAvoy (2002), Pretes (2002) and Pitchford (2006), the scant presence of cultural products and activities are limiting the possibilities of the Lacandon to offer a less stereotyped and essentialist image of their culture.

In terms of benefit sharing and equity of treatment, Reygadas et al. (2006) observes that in Lacanjá Chansayab the different government programmes have only favoured a very limited group of families, and within these there are important imbalances between women and men. Most of the projects are controlled by men aged between 25 and 45 years old, who also monopolise the main public jobs. 'Far from a truly communal appropriation of tourism and archaeological income, a pattern of family or private monopolisation of natural and tourist resources has prevailed' (p.84). PastorAlfonso et al. (2012) point out that the participation of women in community groups is often merely a strategy to attract funding. For Valle-García (2014), alternative tourism has not achieved sustainable objectives in Lacanjá Chansayab. In fact, top-down strategies and a lack of community participation in tourism development has led to inter- and intra-ethnic conflicts, as well as marginalisation.

Even though recent collaborative studies with Lacandon entrepreneurs show an increasingly greater presence of women in traditional male roles (guides, managers, etc.), a growing interest in cultural revival and a more balanced distribution of power 
among neighbouring groups, tourism in the Lacandon Jungle is still far from a situation of 'ex situ quasi-empowerment'.

\section{Conclusions}

Notwithstanding the existence of several chronological singularities and variations, it can be said that the evolution of the relationship between tourism and the Lacandon mostly follows the stages described in Weaver's model (2010). However, in order to apply this model to indigenous peoples in Mexico or other Latin American countries it is essential to consider certain crucial differences.

Pre-colonial history has left a strong imprint on the majority of Latin American countries where many indigenous communities have gone through 'colonial' processes under the rule of pre-Hispanic empires. Besides archaeological sites and artistic remains, those processes have left behind an important cultural and social legacy. Therefore, any analysis of the evolution of tourism in Latin America should bear in mind pre-Hispanic history.

The four countries analysed by Weaver have attained 'economically developed status', indigenous tourism has evolved 'within well-articulated and sophisticated domestic and international tourism systems' and there is a 'relatively long participation and the increasing visibility of indigenous culture and peoples within these tourism systems' (Weaver, 2010, p.46). Conversely, the UN regards most Latin America countries as developing economies; although their tourism systems are improving, they are not yet fully articulated and indigenous tourism initiatives are comparatively new.

As in Weaver' cases, the indigenous peoples of Latin America are suffering marginalisation, discrimination and hardship. However, in Guatemala, Bolivia and Ecuador, for instance, they are not 'ethnic minorities', but quite the opposite. 
Furthermore, the presence of a large mestizo society prevents a 'clear formal distinction between "indigenous" and "nonindigenous" residents' (Weaver, 2010, p.49), the collection of statistical data often being a difficult task (UNPII, 2004).

An analysis of the indigenous peoples of Latin America must also take into consideration the role of post-colonial governments, since in many cases, such as Mexico, comprehensive assimilation policies have been implemented in order to reinforce the national identity (Bonfil Batalla, 1989).

In the Lacandon case, the lack of mass transportation networks and the recent development of indigenous tourism has led to a situation in which the fourth and fifth stages have run concurrently. And, as in many Latin American countries, even without the in situ presence of tourists due to transportation problems, the Lacandon have benefitted from trading opportunities in handicrafts providing with much needed hard cash. Even though the characteristics of the sixth stage have yet to materialise, the outlook for ex situ quasi-empowerment is promising.

Despite the fact that Weaver doubts the convenience of including the first stage inasmuch as pre-European travel cannot be conventionally thought of as a form of indigenous tourism, in this case study it was characterised by the Lacandon's complex visiting rules and rituals. A better understanding of indigenous peoples' traditional hospitality practices could give us important clues as to the development of a less Eurocentric indigenous tourism industry focusing more on local values.

In light of the above, Weaver's model opens up interesting opportunities for further analysis in the field of indigenous tourism in Latin America and other developing regions of the world.

\section{References}


Baer, P., \& Merrifield, W., R. (1972). Los lacandones de México: Dos estudios [Two studies of the Lacandones of Mexico] (C. Viqueira Trans.). Instituto Nacional Indigenista.

Blom, F. (1954). Ossuaries, cremation and secondary burials among the Maya of Chiapas, Mexico. Journal De La Société Des Américanistes, 43(1), 123-136.

Bonfil Batalla, G. (1989). México profundo: Una civilización negada (2nd ed.). México, D.F., México: Grijalbo.

Boremanse, D. (1989). Ortogénesis en la literatura maya lacandona. Mesoamérica, 10(17), 61-104.

Boremanse, D. (1998). Hach winik: The Lacandon Maya of Chiapas, Southern Mexico. New York, NY: University Press of Colorado.

Boremanse, D. (2006). Cuentos y mitología de los lacandones: Contribución al estudio de la tradición oral maya. Guatemala: Academia de Geografía e Historia de Guatemala.

Boremanse, D. (2007). K'in yah: Divination ritual in lacandon maya religion. Mesoamérica, 28(49), 114-135.

Bruce, R. (1968). Gramática del lacandón. México: Instituto Nacional de Antropología e Historia.

Bruce, R. (1976). The popol vuh and the book of chan k'in. Estudios de Cultura Maya, 10, 173-209.

Bruce, R. (1979). Lacandon dream symbolism: Dream symbolism and interpretation among the Lacandon Mayas of Chiapas, Mexico. Mexico, D.F.: Editiones Euroamericanas.

Butler, R., \& Hinch, T. (1996). Tourism and indigenous peoples (1st ed.). London ; Boston: International Thompson Business Press. 
Buultjens, J., \& Fuller, D. (Eds.). (2007). Striving for sustainability: Case studies in indigenous tourism. Lismore, N.S.W.: Southern Cross University Press.

Calleros-Rodríguez, H. (2014). Land, conflict, and political process: The case of the Lacandon community, Chiapas, Mexico (1972-2012). Journal of Peasant Studies, $41(1), 127-155$.

Carr, A., Ruhanen, L., \& Whitford, M. M. (2016). Indigenous peoples and tourism: The challenges and opportunities for sustainable tourism. Journal of Sustainable Tourism, 24(8-9), 1067-1079.

de Vos, J. (1980). La paz de dios y del rey: La conquista de la selva lacandona 15251821. México, DF: Fonapas/Chiapas.

de Vos, J. (2002). Una tierra para sembrar sueños: Historia reciente de la Selva Lacandona. México: Centro de Investigaciones y Estudios Superiores en Antropología Social.

Diemont, S., \& Martin, J. (2009). Lacandon Maya ecosystem management: Sustainable design for subsistence and environmental restoration. Ecological Applications, 19(1), 254-266.

Durand, L., Figueroa, F., \& Trench, T. (2012). Inclusión, exclusión y estrategias de participación en la reserva de la biosfera montes azules. In L. Durand, F. Figueroa \& M. Guzmán (Eds.), La naturaleza en contexto: Hacia una ecología política mexicana (pp. 237-267). México, D.F.: Universidad Nacional Autónoma de México.

Eroza Solana, E. (2006). Lacandones (Pueblos indígenas del México contemporáneo). México, D.F.: Comisión Nacional para el Desarrollo de los Pueblos Indígenas.

Esman, M. R. (1984). Tourism as ethnic preservation: The Cajuns of Louisiana. Annals of Tourism Research, 11(3), 451-467. 
Espeso-Molinero, P. (2018). Collaborative capacity building as a resilience strategy for tourism development in indigenous Mexico. In J. M. Cheer, \& A. A. Lew (Eds.), Tourism, resilience, and sustainability: Adapting to social, political and economic change (pp. 184-201). London: Routledge.

Espeso-Molinero, P., Carlisle, S., \& Pastor-Alfonso, M. J. (2016). Knowledge dialogue through indigenous tourism product design: A collaborative research process with the Lacandon of Chiapas, Mexico. Journal of Sustainable Tourism, 24(8-9), 13311349.

Henderson, J. (2003). Ethnic heritage as a tourist attraction: The Peranakans of Singapore. International Journal of Heritage Studies, 9(1), 27-44.

Hernandez Cruz, R. E., Bello-Baltazar, E., Montoya Gómez, G., \& Estrada Lugo, E. I. J. (2005). Social adaptation: Ecotourism in the Lacandon forest. Annals of Tourism Research, 32(3), 610-627.

Hinch, T., \& Butler, R. (2007). Introduction: Revisiting common ground. In Richard Butler, \& Tom Hinch (Eds.), Tourism and indigenous peoples: Issues and implications (pp. 1-12). Oxford: Butterworth-Heinemann.

Kashanipour, R. A., \& McGee, R. J. (2004). Northern Lacandon Maya medicinal plant use in the communities of Lacanjá Chan Sayab and Naha', Chiapas, Mexico. Journal of Ecological Anthropology, 8, 47-66.

Lemelin, R. H., \& Blangy, S. (2009). Introduction to the special issue on aboriginal ecotourism. Journal of Ecotourism, 8(2), 77-81.

López, G., \& Palomino, B. (2008). Políticas públicas y ecoturismo en comunidades indígenas de México. Teoría Y Praxis, (5), 33-50. 
López, G., \& Palomino, B. (2012). Guía de apoyos federales para el desarrollo del turismo de naturaleza en México. (Informe de resultados). México, D.F: SECTURCONACYT.

Marion Singer, M. (1991). Los hombres de la selva: Un estudio de tecnología cultural en medio selvático. México, D.F.: Instituto Nacional de Antropología e Historia.

Marion Singer, M. (1999). El poder de las hijas de luna: Sistema simbólico y organización social de los lacandones. México, DF: Plaza y Valdés.

Marion Singer, M. (2000). Bajo la sombra de la gran ceiba: La cosmovisión de los lacandones. Desacatos. Revista De Antropología Social, (5), 45-56.

Martínez Cobo, J. R. (1986). Study of the problem of discrimination against indigenous populations. ( No. UN-Document E/CN. 4 Sub.). New York, NY: United Nations. McGee, R. J. (1990). Life, ritual, and religion among the Lacandon Maya. Belmont, California: Wadsworth Publishing Company.

McGee, R. J. (2002). Watching Lacandon Maya lives. Boston: Allyn and Bacon.

McGee, R. J., \& González, B. (1999). Economics, women, and work in the Lacandon Jungle. Frontiers, 20(2), 175-189.

McIntosh, A. J., \& Ryan, C. (2007). The market perspective of indigenous tourism: Opportunities for business development. In Richard Butler, \& Tom Hinch (Eds.), Tourism and indigenous peoples (pp. 73-83). Oxford: Butterworth-Heinemann.

McIntosh, A. J., Zygadlo, F. K., \& Matunga, H. (2004). Rethinking Maori tourism. Asia Pacific Journal of Tourism Research, 9(4), 331-352.

Nations, J. (1979). Population ecology on the Lacandon Maya (Southern Methodist University).

Nations, J., \& Clark, J. (1983). The bows and arrows of the Lacandon Maya. Archaeology, 36(1), 36-43. 
United Nations Secretariat, Permanent Forum on Indigenous Issues (UNPFII) (2004) 'World Bank Contribution to the Expert Workshop on data collection and disaggregation for Indigenous Peoples'. PFII/2004/WS.1/11

Palka, J. W. (2005). Unconquered Lacandon Maya: Ethnohistory and archaeology of indigenous culture change. Gainesville: University Press of Florida.

Palomino, B., \& López, G. (2007). Evaluación 2006 del programa ecoturismo en zonas indígenas. (Informe Técnico).Comisión Nacional para el Desarrollo de los Pueblos Indígenas. Retrieved from http://ru.iiec.unam.mx/2370/

Pastor-Alfonso, M. J. (2012). Turismo y cambio en el entorno de los lacandones. Chiapas, México. Pasos. Revista De Turismo Y Patrimonio Cultural, 10(1), 99107.

Pastor-Alfonso, M. J., \& Gómez López, D. (2010). Impactos socioculturales en el turismo comunitario. Una visión desde los pueblos implicados (Selva Lacandona, Chiapas, México). Salamanca: Editorial Agua Clara.

Pastor-Alfonso, M. J., Gómez López, D., \& Espeso-Molinero, P. (2012). Turismo comunitario y sus consecuencias entre los lacandones de Chiapas: Organismos y sistemas de apoyo. In A. Santana, A. J. Rodríguez Darias \& P. Díaz Rodríguez (Eds.), Responsabilidad y turismo (pp. 23-43). Tenerife: PASOS, Revista de Turismo y Patrimonio Cultural. Retrieved from http://www.pasosonline.org/Paginas/e-book_10.htm

Perera, V., \& Bruce, R. (1985). The last lords of Palenque: The Lacandon Mayas of the Mexican rain forest. Berkeley, CA: University of California Press.

Reygadas, L., Ramos, T., Montoya Gómez, G., Hernández, F., \& Velasco, A. (2006). Estilos de manejo y gestión de proyectos ecoturísticos en la selva lacandona de Chiapas, México. In R. Guevara Ramos (Ed.), Estudios multidisciplinarios en 
turismo. volumen 1 (pp. 71-102). México: Secretaria de Turismo, Red de Investigadores y Centros de Investigación en Turismo. Retrieved from http://bibliotecas.umar.mx/publicaciones/Estudios_versi\%C3\%B3n\%20electr\%C3 $\underline{\text { B3nica.pdf\#page }=72}$

Ryan, C., \& Aicken, M. (2005). Indigenous tourism: The commodification and management of culture. Amsterdam; San Diego, CA; Oxford: Elsevier.

Smith, V. L. (1977). Hosts and guests: The anthropology of tourism. Philadelphia, PA: University of Pennsylvania Press.

Smith, V. L. (1989). Eskimo tourism: Micro-models and marginal men. In V. L. Smith (Ed.), (2nd ed., pp. 55-82). Philadelphia, PA: University of Pennsylvania Press.

Soustelle, J. (1935/2008). En la selva de Chiapas con los lacandones. Históricas: Boletín Del Instituto De Investigaciones Históricas, UNAM, (83), 14-19.

Tozzer, A. M. (1907). A comparative study of the Mayas and the Lacandones. New York, NY: The Archaeological Institute of America. The MacMillan Company. Trench, T. (2005). Representaciones y sus impactos: El caso de los lacandones en la Selva Lacandona. Liminar. Estudios Sociales y Humanísticos, 3(2), 48-69.

Trench, T. (2008). From "orphans of the state" to the comunidad conservacionista institucional: The case of the Lacandon community, Chiapas. Identities, 15(5), 607634.

Valle-García, S. (2014). Ecotourism: Sustainable indigenous policies and its effects in Mayan communities, southern Mexico. In C. A. Brebbia, S. Favro \& F. D. Pineda (Eds.), Sustainable tourism VI (pp. 239-250). Southampton, UK: WIT Press.

Villa Rojas, A. (1985). Estudios etnológicos: Los mayas. México, D.F.: Universidad Nacional Autónoma de México. 
Weaver, D. B. (2010). Indigenous tourism stages and their implications for sustainability. Journal of Sustainable Tourism, 18(1), 43-60.

7893 words 